\title{
Effectiveness of Health Education on HIV / AIDS Detection towards Family Knowledge and Support in Implementation of Pregnant Women VCT
}

\author{
Muii Rahayu ${ }^{1)}$ Wahyu Puijastuti²), Arfiana ${ }^{3)}$ \\ Mujirahayu11ipa416@gmail.com \\ Semarang Health Polytechnic \\ Magelang Midwifery Graduate Program
}

\begin{abstract}
Background: HIV / AIDS cases in Indonesia has increased. In 2015 there were 30,935 people with HIV positive and 7,185 people with AIDS, while in 2016 until January 2017, 41,250 people with HIV positive and 7,491 people with AIDS. Various efforts have been made to prevent and resolve HIV / AIDS transmission, one of which is VCT (Voluntary Counseling and Testing) for pregnant women. VCT is a recommended program for early detection of HIV transmission.

Purpose: To explore the effectiveness of health education on HIV/AIDS detection towards family knowledge and support implementation of pregnant women VCT needed family knowledge about HIV/AIDS detection and family support in implementation of VCT pregnant women.

Methods: The type of this research is experimental research, the research time used is prospective longitudinal. The population in this study is the family of pregnant women who have not done VCT in the working area of Public Health Center Parakan in 2018 as many as 42 people with total sampling technique. Bivariate analysis with Wilcoxon test.

Results: The results showed that there was a difference of knowledge level and family support between before and after receiving health education with knowledge level ( $\mathrm{p}$ value $=0,000)$ and $\mathrm{Z}$-score $=-5,405$, and Support $(\mathrm{p}$ value $=0.000)$ and $\mathrm{Z}$-score $=-4,96$

Conclusion: Family of pregnant women should be more actively seeking information from various health media about HIV / AIDS detection so as to provide support for family members, especially pregnant women to do VCT. To improve the coverage of HIV / AIDS implementation, it is recommended for health workers to improve their health promotion strategies especially on HIV / AIDS detection. As well as providing access to information such as leaflets and leaflets at every posyandu activity, class of pregnant women
\end{abstract}

Keyword : Knowledge, Support, Family, VCT, HIV/AIDS

1),2),3) Midwifery Study Program of Magelang, Semarang Health Polytechnic

Background. AIDS (Acquired Immunodeficiency Syndrome) is a group of symptoms or diseases caused by a decrease in the body's immunity caused by infection with the HIV (Human Immunodeficiency Virus) virus. Around 38.5 million people in the world are infected with the HIV virus at the end of 2016, with various age levels. A total of 36.2 million people infected with the HIV virus were adolescents, followed by 17.8 million women in the world infected with the HIV virus, 16.7 million men and 2.26 million children under 15 years, of all HIV / AIDS sufferers 1.0 million people had died (WHO, 2017). 
About $52.10 \%$ of cases of HIV / AIDS in the world are experienced by women and children under 15 years. Whereas in the South and Southeast Asian regions the highest HIV / AIDS cases were experienced by women at $53 \%$ according to WHO (2017). This increase is due to risky sexual relations. The phenomenon of HIV / AIDS cases has contributed to the high maternal mortality rate (MMR) in the world. The high number of infections in pregnant women can also increase the risk of transmission of infection to the fetus. More than $90 \%$ of children infected with HIV are from their mothers. The risk of transmitting the HIV / AIDS virus from mother to child occurs during pregnancy, which is approximately $5-10 \%$, during delivery $10-20 \%$ and 5-20\% during breastfeeding (Ministry of Health, 2012).

HIV / AIDS cases in Indonesia have increased compared to 2015 which amounted to 30,935 HIV positive people and 7,185 people with AIDS, while in 2016 until January 2017 around 41,250 people were HIV positive and 7,491 people with AIDS (Ministry of Health, 2017) . This increase in figure is quite alarming for the country of Indonesia. One of the provinces in Central Java, where in 2015 the number of people with HIV / AIDS was 3,005 HIV positive people and 963 people with AIDS increased to 4,032 HIV positive people and 1402 people with AIDS in 2016 (Central Java Provincial Health Office, 2017). This has become a shadow that disturbs health figures in Central Java, even Central Java ranks 4th with the highest HIV / AIDS cases in Indonesia. Temanggung Regency, which is part of the region in Central Java, is also registered as a region with HIV / AIDS cases. In July 2016 the KPA (AIDS
Protection Commission) reported cases of HIV / AIDS in Temanggung Regency in the amount of 342 cases, with details of 193 cases of HIV and 149 cases of AIDS. A total of 163 people with HIV / AIDS cases have died, 8 of them toddlers with HIV / AIDS (KPA, 2017).

Various efforts have been made to prevent and overcome the transmission of HIV / AIDS, one of the efforts made is VCT (Voluntary Counseling and Testing). VCT is a program that is recommended to detect early transmission of the HIV virus, but there are still many pregnant women who have not done VCT. Of the total of all pregnant women in Temanggung Regency, 11,624 thousand new pregnant women around 998 per September 2017 pregnant women who have taken VCT. VCT programs in Temanggung District have been required with several health care facilities that have available VCT services, namely in the Kaloran Public Health Center, Parakan Health Center, Pare Health Center, Ngadirejo Health Center, Bejen Health Center, Fur Puskesma and Temanggung Health Center, also in Djojonegoro Hospital and RSK Ngesti Waluyo. However, the coverage of VCT examinations for pregnant women is still far from the target, the low VCT coverage rate is motivated by the stigma of the community, who think that people suffering from HIV / AIDS need to be shunned because the disease is very dangerous and contagious.

HIV / AIDS sufferers are very vulnerable to discrimination, exclusion, violence, or detention, this is the reason why the number of HIV / AIDS cases is difficult to find and overcome, because people who suffer from HIV / AIDS become frightened of stigma and discrimination from the shame of doing 
HIV testing, embarrassed to start treatment, and the emergence of reluctance to receive education about HIV / AIDS (UNICEF, 2012).

Family support is important in a variety of circumstances. This family support will motivate mothers to be more aware of their health, such as awareness of HIV / AIDS screening in pregnant women, adherence to antiretroviral consumption for pregnant women with HIV / AIDS. This is supported by research conducted by Poetri (2013) which states that from the results of the research he conducted there was a significant relationship between family support for the patient's unit with HIV / AIDS in taking antiretroviral drugs. Therefore family support will greatly influence the achievement of increasing awareness of pregnant women in VCT.

Based on preliminary studies conducted by the researchers, of 10 people consisting of 5 pregnant women and 5 family members of pregnant women who were interviewed, 4 out of 5 pregnant women did not do VCT because pregnant women did not know what VCT was and the goals and benefits, and 1 person has not done VCT because they do not have time to check. Whereas from the interviews of 5 families of pregnant women the results of all families with pregnant women did not know about VCT, the purpose of VCT and the benefits of VCT. From the background above the authors are interested in examining the "Effectiveness of Health Education Detection of HIV / AIDS to Increase Family Knowledge and Support in the Implementation of VCT for Pregnant Women"

Objective. The study was conducted in the working area of Parakan Health Center, Temanggung Regency on March 2018. The population in this study was the families of pregnant women who had not yet implemented VCT.

Method. This type of research is experimental research with crosssectional approach using primary and secondary data. Sampling in this study using total sampling technique. The bivariate test in this study used Wilcoxon test, with the interpretation of the results at $p$-value $\leq 0.05$.

\section{Results and Discussion. \\ Results}

1. Health Education HIV / AIDS Detection Analysis towards Increased Family Knowledge. Table 1. Comparative Tests of Family Knowledge Level Before and After Detection HIV / AIDS Health Education.

\begin{tabular}{|c|c|c|c|c|c|c|}
\hline & & $\mathrm{N}$ & $\begin{array}{c}\mathrm{Me} \\
\text { an } \\
\mathrm{Ra} \\
\mathrm{nk}\end{array}$ & $\begin{array}{l}\text { Sum of } \\
\text { Ranks }\end{array}$ & $\begin{array}{c}\mathrm{P}- \\
\text { value }\end{array}$ & $\mathrm{Z}$ \\
\hline \multirow{4}{*}{$\begin{array}{l}\text { Post } \\
\text { Pend } \\
\text { kes - } \\
\text { Pre } \\
\text { Pend } \\
\text { kes }\end{array}$} & $\begin{array}{c}\text { Negative } \\
\text { Ranks }\end{array}$ & $1^{\mathrm{A}}$ & $\begin{array}{c}3.5 \\
0\end{array}$ & 3.50 & .000 & $\begin{array}{c}- \\
5.405 \\
\end{array}$ \\
\hline & $\begin{array}{c}\text { Positive } \\
\text { Ranks }\end{array}$ & $38^{\mathrm{b}}$ & $\begin{array}{l}20 . \\
43\end{array}$ & 776.50 & & \\
\hline & Ties & $3^{\mathrm{c}}$ & & & & \\
\hline & Total & 42 & & & & \\
\hline
\end{tabular}

Results comparative test 2 groups of data paired with abnormal data distribution obtained results that the $p$-value is $0,00050,05$ which means that Ho is rejected and $\mathrm{Ha}$ is accepted, so there are significant differences from the level of family knowledge before and after getting health education HIV / AIDS detection. The Z-score from the results of the comparative analysis test 2 groups of data paired with abnormal data distribution, namely $-5,405$ which means that there is a difference in the level of family knowledge as much as $5 \mathrm{x}$ after being given health education on HIV / AIDS detection. However, from 42 respondents who had received health education on HIV / 
AIDS detection, there was 1 respondent whose level of knowledge on HIV / AIDS detection declined and 3 people remained.

2. Analysis of Family Support in the Implementation of VCT for Pregnant Women

Table 2. Comparative Tests of Family Support in the Implementation of VCT Pregnant Women Before and After Health Education HIV / AIDS Detection

\begin{tabular}{|c|c|c|c|c|c|c|}
\hline & & $\mathrm{N}$ & $\begin{array}{c}\text { Mean } \\
\text { Rank } \\
\text { of }\end{array}$ & $\begin{array}{l}\text { Sum of } \\
\text { Ranks }\end{array}$ & $\begin{array}{c}\mathrm{P}- \\
\text { value }\end{array}$ & $\mathrm{Z}$ \\
\hline \multirow{4}{*}{$\begin{array}{l}\text { Post } \\
\text { Supp } \\
\text { ort - } \\
\text { Pre } \\
\text { Supp } \\
\text { ort }\end{array}$} & $\begin{array}{c}\text { Negative } \\
\text { Ranks }\end{array}$ & $0^{\mathrm{a}}$ & 0,00 & 0,00 & 0,000 & $-4,969$ \\
\hline & $\begin{array}{c}\text { Positive } \\
\text { Ranks }\end{array}$ & $32^{\mathrm{b}}$ & 16,50 & 528,00 & & \\
\hline & Ties & $10^{c}$ & & & & \\
\hline & Total & 42 & & & & \\
\hline
\end{tabular}

Comparative test results 2 groups of data paired with abnormal data distribution obtained results that $p$ value is $0,000 \leq 0.05$, which means that $\mathrm{Ho}$ is rejected and $\mathrm{Ha}$ is accepted, so there are significant differences from family support in implementing VCT for pregnant women before and after health education for HIV / AIDS detection. The Z-score from the comparative analysis of 2 data groups paired with abnormal data distribution, namely $-4,969$, which means there was a difference of $4 x$ family support after receiving health education on HIV / AIDS detection, but from 42 respondents there were 10 respondents who did not experience change in providing support.

\section{Discussion.}

1. Analysis of Health Education HIV / AIDS Detection against Increased Family Knowledge.

Health education is a health effort aimed at increasing people's awareness, willingness and ability to live healthy lives and participate in health efforts. This is in line with the research conducted by
Buamona, Kumaat, \& Malara (2017) in his research entitled the effect of health education on changes in the level of influence of health education on the level of knowledge of Basic Life Assistance (Bhd) in traffic accidents in Sanana 1 District High School students The Sula Islands of North Maluku obtained the analysis using the wicoxon test obtained p-value 0.033 or probabilities below 0.05. Thus Ha is accepted, namely there is an influence between health education on the level of knowledge of basic life assistance in traffic accidents in students of Sanana 1 Public High School, Sula Islands District, North Maluku.

In this study to find out the differences in the level of family knowledge before and after receiving health education on HIV / AIDS detection a comparative test was conducted on 2 groups of data paired with abnormal data distribution. Comparative test results of 2 groups of data paired with abnormal data distribution using Wilcoxon test obtained the results of $p$-value of $0,00050.05$, which means that Ho is rejected and $\mathrm{Ha}$ is accepted, so there are significant differences from the level of family knowledge before and after health education HIV / AIDS detection.

The Z-score from the comparative analysis of 2 data groups paired with abnormal data distribution from this study is 5.405, which means there is a difference in the level of family knowledge as much as 5x after receiving health education on HIV / AIDS detection. The existence of 
an increase in the level of knowledge before and after getting health education is seen from the large number of $p$-values, with an explanation that there is a difference if the p-value is $\leq \alpha$ (0.05). This statement is in accordance with the theory put forward by Notoatmodjo (2012) that there are differences in the level of knowledge before and after getting a health education that is significant if the $p$-value is $\leq \alpha$ (0.05). Supported by the results of research conducted by AC Sari, Maliya, \& Kartinah (2015) in the results of the study mentioning there were differences in pretest and posttest knowledge in the treatment group with the results of Wilcoxon Signed Rank Test knowledge in the treatment group obtained $p$-value amounting to 0.001 ( $p$-value $<0.05$ ). As well as supported by research conducted by Astri, Winarni, \& Dharmawan (2016) the effect of providing reproductive health education on the level of knowledge of early adolescents in elementary school in the Bandungan Tourism area, Semarang Regency in 2016, the results of the study bivariate analysis with Two Way Anova test showed that there is an effect of giving reproductive health education to the level of knowledge of early adolescents with a $\rho$-value of 0.0001 ( $\rho$-value $<\alpha)$ in other words Ho is rejected.

In providing health education researchers use video media to help accelerate the process of understanding respondents to HIV / AIDS detection material. However, from the comparative test results, 2 groups of paired data obtained 4 results from 42 respondents, 1 respondent experienced a decrease in knowledge level and 3 of them did not experience an increase or decrease, this indicates that during the material delivery process there are several factors that hinder the delivery or acceptance of material by respondents, as well as the effectiveness of the use of media which can only help respondents remember as much as $50 \%$ of what they see and hear. So from here there is a possibility that the respondent has decreased or remained in the level of knowledge.

This opinion is in accordance with the theory put forward by Nursalam \& Efendi (2012) that from listening and seeing, respondents will remember $50 \%$ of what they hear and see. This theory is supported by research conducted by Lia \& Wardani (2017) who in his research stated that from the screening of reproductive health videos and the dangers of premarital sex obtained from the results of bivariate analysis namely pvalue $0.025<\alpha$ 0.05 , which means there is influence of video media on increased knowledge about reproductive health and the dangers of premarital sex. So from that it can be said that the use of video media in the delivery of material has an influence in increasing knowledge of the material provided.

2. Analysis of Family Support in the Implementation of VCT for Pregnant Women

Increasing family knowledge about HIV / AIDS detection will 
be one of the predisposing factors for changes in behavior of an individual in accordance with the theory presented by Lawrence Green (1980) in Ali (2010). predisposing factors in which discuss knowledge where the low level of knowledge will affect behavior.

The low level of one's knowledge about HIV / AIDS is a background of society stigmatized in people with HIV / AIDS, this causes everyone or even a pregnant mother to be reluctant to do VCT, this statement is supported by research conducted by Kaliti, Indrati, \& Kartikasari (2012) about attitudes and actions of mothers with HIV / AIDS on community stigma and discrimination in the city of Semarang with the result that stigma and discrimination in society make PLWHA mothers unwilling to interact with the community and tend to close status. This research is also supported by research conducted by Sari, Sulistyono, \& Notobroto (2016) that the results of statistical tests show that $p$-value $(0,000)<\alpha$ (0.05) means that stigmatization has a significant relationship with the participation of pregnant women in HIV testing after counseling by health workers at the Turi Health Center in Lamongan Regency. So that in changing the behavior of an individual also needs to need the support of people who are important to him in accordance with the theory put forward by Cohen \& Smet (1996) in Harnilawati (2013) where social support is an impulse that creates a beneficial condition for an individual obtained from others that can be trusted, so that the individual knows that there are other people who pay attention, respect and love him. In addition, from studies of family support that have been carried out, social support is used as family coping, both external and internal support because it proves very useful.

From the data analysis it was obtained that the average value of family support before health education was 10.50 and after getting health education which was 12.64 , so that it could be seen that there was an increase in family support in the implementation of VCT after obtaining health education. To find out that there is an increase in family support in implementing VCT, pregnant women are made a comparative test of 2 groups of data paired with abnormal data distribution. From the results of the comparative test 2 groups of data paired with abnormal data distribution showed that the p-value was $0,00050.05$, which means that Ho is rejected and $\mathrm{Ha}$ is accepted, meaning there are significant differences from family support in VCT implementation before and after giving health education HIV / AIDS detection.

The Z-score from the comparative analysis data of 2 groups paired with abnormal data distribution, namely $-4,969$ means that there is a difference in family support as much as $4 \mathrm{x}$ after receiving health education on HIV / AIDS detection, but from 42 respondents there were 10 respondents who did not experience changes in provide support. This can be due to busy 
work and environmental conditions so that pregnant women feel the support given by their family is lacking.

From the results of statistical tests, it can be seen that there are differences in the level of family support before and after obtaining health education for HIV / AIDS detection, this indicates that the higher the family's role in providing support to family members will increase the behavior change of an individual. Likewise with increasing family knowledge that can improve changes in family attitudes in providing support to family members. This opinion is in accordance with the theory conveyed by Nursalam and Ferry Efendi (2012) which explains that the change in attitude plays a role in fostering the maintenance of healthy behavior and plays an active role in optimizing health status, this is supported by research conducted by Halim, Syamsulhuda, and Kusumawati (2016) that from the results of bivariate analysis shows that the statistical test with a significance level of $5 \%$ is obtained $\mathrm{p}$ value 0.002, which means that statistically there is a relationship between attitudes and HIV examination behavior

\section{Conclusions and Suggestions.}

The results Wilcoxon test from the level of pre and post health education obtained by the results of $p$-value of $0,000,0.05$, meaning that Ho is rejected and $\mathrm{Ha}$ is accepted, so there are significant differences from the level of family knowledge before and after getting health education for HIV / AIDS detection. Z-score $=-5,405$, which means there is a difference in the level of family knowledge as much as 5 times after getting HIV / AIDS detection health education.

The results Wilcoxon test from the level of family support pre and post health education obtained $p$-value of $0,00050,05$, meaning that Ho was rejected and Ha was accepted, so there were significant differences from family support in VCT implementation before and after receiving health education. Z-score $=-4,969$, meaning that there is a difference of $4 \mathrm{x}$ family support after being given health education on HIV / AIDS detection.

\section{References}

Ali, Z. 2010. Basics of Public Health Education and Health Promotion. Jakarta: TIM.

Arikunto, S. 2013. Research Procedures; A Practice Approach. Jakarta: Rineka Cipta.

Astri, LA, Winarni, S., \& Dharmawan, Y. 2016. Effect of providing reproductive health education on the level of knowledge of early adolescents in primary school in the Bandungan Tourism area, Semarang Regency in 2016. Health Journal Public, 4, 213-219. Retrieved from https://ejournal3.undip.ac.id/inde x.php/jkm/article/view/13999

Budiarti, S. 2016. Overview of Family Support for HIV / AIDS Patients. Health Journal.

Buamona, S., Kumaat, LT, \& Malara, RT 2017. Effect of health education on the level of knowledge of basic life assistance (BHD) in traffic accidents in students of Sanana 1 Public High School, Sula Islands Regency, 
North Maluku. E-Journal of Nursing (e-Kp), 5, 1-5.

Central Java Provincial Health Office. 2017. Quarterly Health Handbook 2. Semarang: Central Java Provincial Health Office.

Edyati, L. 2014. Video media on personal hygiene knowledge and attitudes of SD Negeri 1 Kepek Pengasih students, 1-20.

Effendy, Nasrul. 2010. Basics of public health nursing science. Jakarta: EGC

Friedman, Marilyn M. 2010. Textbooks: Family Motivation Research, Theory, \& Practice. Jakarta: EGC.

Halim, Y., BM, S., \& Kusumawati, A. 2016. Factors Associated with Behavior of Pregnant Women in HIV Examination in the Work Area of Semarang City Halmahera Health Center, 4, 395-405.

Harnilawati. 2013. The Concept and Process of Family Care. Sulawesi: As Salam Library.

Hidayat, AAA 2014. Midwifery Research Methods and Data Analysis Techniques Application Examples of Case Studies. Jakarta: Salemba Medika.

Irianto, Koes. 2014. Epidemiology of infectious diseases and noninfectious clinical guidelines. Bandung: Alfabeta

Jannah, SR, Agusman, F., \& Wijayanti, H. 2014. Relationship between Women's Sex Workers (WPS) Knowledge About Voluntary Counseling Testing (VCT) Against the Behavior of Voluntary Counseling Testing (VCT) in PKBI City Griya Asa Clinic.

Kaliti, MI, Indrati, R., \& Kartikasari, Y. 2012. Attitudes and Actions of Mothers with HIV and AIDS
Against Stigma and Discrimination in the City of Semarang, 8(1).

RI Ministry of Health. 2012. National Guidelines for Prevention of HIV Transmission from Mother to Child (PPIA). Jakarta: RI Ministry of Health.

RI Ministry of Health. 2017. Indonesia Health Profile 2016. Jakarta: RI Ministry of Health.

Republic of Indonesia Ministry of Health. (2015). Management Guidelines for Prevention of HIV and Syphilis Transmission Programs from Mother to Child. Jakarta: RI Ministry of Health.

KPA. 2017. Temanggung HIV / AIDS Case Data. Temanggung: Temanggung Regency Health Office.

Kristanto, N. 2016. Faculty of Health Sciences Muhammadiyah University of Surakarta 2016.

Kunoli, FJ 2013. Introduction to Epidemiology of Infectious Diseases. Jakarta: TIM.

Lia, K., \& Wardani, AI 2017. Effects of Media Video on Knowledge in Prevention of Premarital Sex Behavior in Middle School Students. Proceedings of the National Seminar, 1-6.

Murtiastutik, D. 2008. Textbooks: Sexually Transmitted Infections. Surabaya: Airlangga University Press.

Nasronudin. 2007. HIV \& AIDS Clinical and Social Molecular Biology Approach. Surabaya: Airlangga University Press.

Nasronudin. 2014. HIV \& AIDS Molecular, Clinical and Social Biology Approaches. Surabaya: Airlangga University Press.

Notoatmodjo, S. 2012. Health Research Methodology. Jakarta: Rineka Cipta. 
Notoatmodjo, S. 2014. Health Promotion and Health Behavior. Jakarta: Rineka Cipta.

Nursalam. 2009. Nursing care in infected patients. Jakarta: Salemba Medika.

Nursalam. 2008. Concept and Application of Nursing Research Methodology: Thesis Guidelines, Thesis, and Nursing Research Instruments. Jakarta: Salemba Medika.

Nursalam \& Efendi, Ferry. 2012. Education in Nursing. Jakarta: Salemba Medika.

Sopiyudin, D. 2014. Statistics for Medicine and Health: Descriptive, Bivariate, and Multivariate, Equipped Using SPSS. Jakarta: Indonesian Epidemiology.

Sari, AC, Maliya, A., \& Kartinah. 2015.Effect of Health Education About Own Breast Examination on Knowledge and Motivation to Do It for Women Aged 30-50 Years in the Village of Joho Mojolaban. Fik Ums.

Sari, PIA, Sulistyono, A., \& Notobroto, HB 2016. Participation of Pregnant Women in HIV Test After Counseling by Health Officers (In the Work Area of Turi Lamongan Health Center) Introduction of HIV AIDS (Human Immunodeficiency Virus / Acquired Immune Deficiency Syndrome). The Indonesian Journal of Public Health, 11 (December), 89-98. https://doi.org/10.20473/ijph.v11i
Sugiyono. $2016 . \quad$ Methods: Quantitative, Qualitative, and $R$ \&D.Bandung: Alfabeta.

Suharto, Nuryanti, E., \& Sutarmi. 2015. Consistency of the Use of Condoms in the Prevention of HIV / AIDS in the Risk Group of Truck Drivers in Blora Regency. Health Journal, 397-402.

Sulistyawati, A., \& Nugraheny, E. 2013. Obstetrics Assistance at Maternity. Jakarta: Salemba Medika.

UNICEF. 2012. Response to HIV \& AIDS. Jakarta: UNICEF Indonesia.

Utari, W., Arneliwati, \& Novayelinda, R. 2011. Effectiveness of health education on increasing family knowledge about acute respiratory infections (ARI), 1-7.

Wawan, A., \& Dewi. 2010. Theory \& Measurement: Knowledge, Attitudes, and Human Behavior. Yogyakarta: Nuha Medika.

WHO. 2017. Contents - HIV global slides Summary of the global HIV epidemic 2016, (July). Retrieved from http://www.who.int/hiv/data/en/

Wulandari, Anita. 2012. Differences in IRT Attitudes in preventing HIV / AIDS before and after health education in Candi Kelurahan, Candisari District, Semarang City.

Zulaikhah, D. 2017. Knowledge and Behavior of Housewives Against VCT Programs in Village $\mathrm{X}$ Parakan Subdistrict, Temanggung Regency. 